\title{
Financing Entrepreneurship in Post-Covid-19 Era: the Islamic Banking and Finance Option
}

\author{
AbdulFattah AbdulGaniyy ${ }^{*}$, Ibraheem Alani AbdulKareem², Aminu \\ AbdulRaheem ${ }^{3}$ \\ ${ }^{1}$ Federal Polytechnic, Kaura Namoda, Zamfara State, Nigeria \\ ${ }^{2}$ Universiti Sultan Zainal Abidin, Terengganu, Malaysia \\ ${ }^{3}$ Mai Idris Alooma Polytechnic Geidam Yobe State, Nigeria
}

\section{Article History}

Received: December, 11 2021 Revised: January, $5^{\text {th }} 2022$ Accepted: January, $11^{\text {th }} 2022$

\begin{abstract}
*Corresponding author:

E-mail: abdulfattah1435

@gmail.com , abuaishah1425@ yahoo.com

Entrepreneurship is the bedrock that propels the development and growth of the economy. Unfortunately, access to finance is the major obstacle faced by entrepreneurs. Conventional banking does not support innovative and dynamic ideas driven by entrepreneurs. They are required to pay back loans with interest collected from conventional banks without regard to the success or failure of their venture. Islamic bank has come to the rescue of entrepreneurs through its inventive Profit and Loss Sharing (PLS) products and services. The objective of this study was to highlight features and products of Islamic banking and finance that are suitable for entrepreneurship. The study was a conceptual and adopted method of reviewing existing literature on financing entrepreneurship and its challenges. The authors concluded that Islamic finance provides a better alternative to conventional finance and provides stability and sustainability to entrepreneurs. The study recommended that government should support and encourage entrepreneurs to cooperate with Islamic banks. There should be continuous public education, especially of the youth on skill acquisition through entrepreneurship centers. The study has implications for the government, policymakers and other stakeholders responsible for providing palliatives to the citizens in the post-covid-19 pandemic. Islamic finance is more aligned and supportive of entrepreneurship, especially through its profit and loss sharing financing.
\end{abstract}

Keywords: Entrepreneurship, Islamic Finance, Islamic Banking, Profit and Loss Sharing (PLS), Covid-19. 


\section{Introduction}

The economic growth and development of any nation depend on entrepreneurship. Small and Medium Enterprises (SME) are tools for generating income, reducing unemployment and keys to globalization and relationship among nations of the world (Riza et al., 2017). SMEs are sources of innovation, dynamism, and productivity (Thaker et al., 2020). They represent $95 \%$ of companies that provide $65 \%$ of employment and $50 \%$ of the global Gross Domestic Products (GDP) (World Trade Report, 2016). They are major contributors to the development and growth of any economy. In spite of these contributions to the economy, SMEs' major obstacle is access to finance. Access to capital is an important requirement for the development of entrepreneurship (Adamu \& Hammawa, 2018; Wale-Awe, 2010). Entrepreneurs do not have sufficient access to financing due to restrictions by conventional banks. In conventional financing, the only available options are either equity or debt financing. Debt financing involves an entrepreneur taking an interest-based loan. It also requires assets like houses, land, cars, or machines as collateral (Robertm et al., 2008). An entrepreneur is required to pay back the amount borrowed as well as a fee expressed in terms of interest. Although equity financing does not require interest payment or collateral, small entrepreneurs do not have sufficient financing for their initial take-off, working capital and long-term investment.

In the face of these restrictions and limitations, entrepreneurs resort to personal saving and internal financing through profits, sale of assets and reduction in working capital extended payment terms and account receivables (Wale-Awe, 2010). Innovative entrepreneurs who are not able to get financing support from conventional banks also opt for bootstrap financing. This is an alternative financing option used by entrepreneurs to get financial assets different from equity and debt. There is also crowdfunding among entrepreneurs. It is online funding controlled by individuals. As it is less controlled, it is a threat to regular financial institutions (Tawfiqi et al., 2018). These financial options are not even popular and available to entrepreneurs, especially in developing countries like Nigeria.

Islamic finance has come to rescue entrepreneurs from these obstacles. Although Islamic finance constitutes less than 1\% of the global financial market (Adedeji, 2021) and is concentrated in a few areas, yet it has a significant impact on the success and welfare of entrepreneurship. Report from Islamic Finance Service Boards (IFSB, 2018) indicates that Islamic Banking Finance Industry recorded an estimated 17\% compound annual growth in the previous five years and had a net worth of $\$ 1.87$ trillion total assets in 2014. Islamic finance that is based on the principles of Shariah offers loans and assistance without interest, thus facilitating entrepreneurship.

\subsection{Objective}

This study aims to highlight features and products of Islamic banking and finance that are suitable for entrepreneurship. It is also to identify the challenges of the entrepreneurs in accessing the facilities provided by Islamic banks. The remaining sections of this study discuss the concept of entrepreneurship and its significant effect on the economy. It also traces the development of entrepreneurship in Nigeria. The influence of Islam on entrepreneurship, features of Islamic finance and banking and challenges of entrepreneurship in accessing their services and products were also discussed. The last section concludes the discussion and offers recommendations. 


\section{Literature Review}

\subsection{Concept of Entrepreneurship}

Entrepreneurship is the process of creating incremental wealth by individuals who assume risks in terms of equity, time and/or career commitment or provide value for some products or service (Robert et al. 2008). It is a series of creative, dynamic, planned activities and/or practices through which individuals attempt to meet needs, create opportunities, and allocate resources to provide products and services (Shehu et al., 2015). The term 'Entrepreneur' was first used by the French philosopher Richard Cantillon in 1755 (Salehi et al., 2011). He described it as a trader with an eye for opportunity and profit. The entrepreneur 'bought at a certain price and sold at an uncertain price, thereby operating at risk'. This means an entrepreneur takes advantage of any economic opportunity, assumes reasonable risks in the expectation of unknown return. It involves generating an idea and turning them into products and /or services. Entrepreneurs within an existing organization are known as intrapreneurship (Akindele, 2016). An entrepreneur takes advantage of any economic opportunity, assumes reasonable risks in the expectation of an unknown return. Small and Medium Entrepreneurship (SME) are tolls for income generation, employment creation and are keys to globalization and relationship among nations of the world (Riza et al., 2017). They are major contributors to the development and growth of any economy (Thaker et al. 2020).

\subsection{Development of Entrepreneurship in Nigeria}

The development of entrepreneurship in Nigeria dates back to the pre-independence era. This includes the establishment of the Nigerian Local Development Board (NLDB) 1946, three Regional Development Boards, 1949 after dissolving NLDB, Federal Loans Board 1956; Yaba Industrial Estate, 1962; and Nigeria Enterprises Promotion Decree (Indigenization Decree) 1972 (Wale-Ale, 2010). There was also the establishment of the National Directorate of Employment (NDE), Small and Medium Enterprises Development Agency of Nigeria (SMEDAN) and Small and Medium Industries Equity Investment Scheme. There were also Finance Institutions, including the Bank of Agriculture (BOA), Nigerian Export-Import Bank, Urban Development Bank and Federal Mortgage Bank of Nigeria (CBN Annual Report, 2010). The Central Bank of Nigeria (CBN) also established the N200 billion Small and Medium Scale Enterprises Guarantee Scheme (Adamu \& Hammawa, 2018). These institutions were interest-based financing. Thus, there was still financial exclusion of those who did not agree with interest-based transactions. More recently, the CBN established non-interest-based intervention schemes. The objectives of these schemes include the promotion of financial inclusion, employment creation, diversification of the economy and empowerment of the agricultural sector (Alaro, 2020). These schemes created opportunities to support business start-up and expansion as well provided affordable security or collateral. Besides, these schemes are said to be Shariah-compliant as they 'trade with money, not in the money.

\subsection{Islam and Entrepreneurship}

The population of Muslims in the world is about 23.5\%, and it continues to grow (Anggadwita et al., 2017). The growth has heightened the desire of Muslims to influence various sectors with Islamic teachings, including Entrepreneurship. Muslim entrepreneurs 
desire to run their businesses in accordance with Islamic teachings. Entrepreneurship is part of the culture of Islam. Islam encourages entrepreneurship that promotes economic activities (Hassan \& Hippler, 2014). It is a religious obligation to seek means of sustenance and not depend on others. Fulfilling religious obligation is a basic inspiration for Muslim entrepreneurs. The religious obligation has two main objectives, which include the Din or relationship with the creator and Muamalat dealing with other creations, including human beings and his environment (Shehu et al., 2015). Muslim entrepreneur is expected to fulfil these objectives in their business venture by complying with the Shariah laws and respecting agreement with fellow human being based on justice and fairness. Even though Islam represents only $23.2 \%$ of the world population (Anggadwita et al., 2017), the teachings and thoughts of Islam have influenced different sectors, including entrepreneurship. Entrepreneurship is part of Islamic culture, and Muslims are expected to be entrepreneurs based on love, cooperation, and generosity. Muslim entrepreneurs are expected to ensure that all business activities are in line with Islamic beliefs as contained in Shariah law. Such entrepreneurship would improve people's welfare by creating jobs, reducing poverty and unemployment among the community. This has a positive impact on the welfare of the people, public revenue, and economic growth of a country.

\subsection{Features of Islamic Banking and Finance}

Islamic banking and finance are based on the principles of Shariah (Islamic law) (Anifowose 2015). Its basic feature includes the prohibition of riba or interest. It also forbids uncertainty (Gharar) and gambling (Maisir). The operation of Islamic banks is based on risksharing, and it prohibits risk-free returns. Profit and Loss Sharing (PLS) is a unique feature of Islamic banking (Hamzah \& Gazali,2015; AbdulGaniyy \& AbdulKareem, 2020), and it is the bedrock of Islamic financing (Salehi et al. 2011). In PLS, return on capital is subject to productivity and allocation of funds is based on how feasible and reliable a project is. The profitability and worthiness of a project are more important than creditworthiness and the ability to pay back the loan and the interest on it. This results in an efficiency of capital allocation. The distribution and allocation of wealth are also equitable. PLS provides incentives to both lenders and entrepreneurs. Islamic banks also provide assistance and loan without charging interest. This promotes entrepreneurship and economic growth (Anifowose, 2015; Ledhem \& Moussaoui, 2021). PLS is also able to stabilize the business of an entrepreneur as the burden of an instalment is less than interest-based financing (Herianingrun et al., 2019). PLS increases savings and does not cause inflation because supply reflects an increase in the real sector. This eventually has a significant positive effect on economic growth. The intermediation function of Islamic banks encourages investors and depositors through PLS (AbdulGaniyy, 2018). The relationship between an entrepreneur and an Islamic bank is based on investment rather than as a debtor who has to pay fixed interest. The attraction of investors and entrepreneurs is on high return by Islamic banks rather than fixed interest. This eradicates obstacles between investors and those who need funds and brings them together to the real sector. Islamic banks are also able to integrate ethical and moral values in banking. Thus, there is a reduction in the effect of harmful products and services like alcohol, tobacco, pornography on society. 
Financing Enterpreneurship in Post-COVID-19 Era: the Islamic Banking and Finance Option

AbdulFattah AbdulGaniyy, Ibraheem Alani AbdulKareem, Aminu AbdulRaheem

Page: 193-201

\subsection{Islamic Banking and Finance Products for Entrepreneurs}

There are two categories of products offered by Islamic Finance. These are equity-based and asset-based financing (Thaker et .al 2020). The equity based include Musharakah and Mudarabah while the asset-based include Murabahah, Ijaarah, Salam, Istisna, Tawarruq and Qardu Hassan. Each of these products will be discussed in relation to their suitability for entrepreneurship.

\section{Musharakah Financing}

This partnership financing involves two or more parties contributing capital for running a business. Profit is shared according to an agreed ratio, while loss is borne based on the capital contribution. The advantage of this is the profit-sharing and possibility of earning higher profit by the active partner depending on the success of the business.

\section{Mudarabah Financing.}

This financing involves two parties in which one party is known as Rabu-l-Maal, who contributes capital, and the other known Mudarib manages the business. Profit is shared on an agreed ratio while loss is borne by Rabu-l-Mal, the Mudarib loses his expertise contribution unless there is negligence on the part of the Mudarib. This is the ideal and most recommended financing for an entrepreneur. He does not contribute capital, and the profitsharing ratio can be negotiated to his advantage.

\section{Murabahah Financing}

This is the most common financing often adopted by Islamic banks. The bank purchases an item required by the entrepreneur and sells it at cost plus mark up. The advantage includes that the entrepreneur is not usually required to provide collateral, while price and mark-up are to be disclosed. The product is ideal for short-term financing and can be used to manage the liquidity of an entrepreneur (AbdulKareem et al., 2020).

\section{Ijarah Financing}

This is a leasing contract between an Islamic finance institution and an entrepreneur. The institution provides an asset or service for a fee. At the expiration of the agreement, the entrepreneur will be given the option of buying the item or the item is disposed of in the open market.

\section{Salam}

This is like a forward sale in conventional finance. In this arrangement, the Islamic bank partners with farmers. The farmers as entrepreneurs are provided with farming tools or items like seeds, fertilizer, tractors etc., for farming. The farmer is required to pay for these items at the time of harvesting with farm products. The bank can now sell these farm products to a third party.

\section{Istisna}

This is similar to Salam mentioned above. Here, manufactured products rather than farm products are involved. The Islamic bank will agree with a manufacturer to produce to a specification of an entrepreneur. Such item is delivered to the entrepreneur who pays in instalments (AbdulKareem et al., 2020). 


\section{Tawarruq Financing}

This is an arrangement in which an entrepreneur will buy an item from an Islamic bank on a deferred payment basis and sell it to a third party on a cash basis. It is also used to manage the liquidity and working capital of entrepreneurship.

\section{Qardu Hassan}

This financing is a short-term credit or loan without interest granted by Islamic banks to an entrepreneur. The latter may be asked to pledge a valuable item as collateral. This is based on the Shariah principle of saving with guarantee or safe-keeping. It should be noted that both Murabahah and Ijarah were not original Islamic financing products. These products have been criticized as being close to interest-based financing under conventional banks. They were developed to meet needs that are not feasible under Musharakah and Mudarabah.

\subsection{Challenges of Islamic Finance for Entrepreneurs}

There are many challenges faced by entrepreneurs in accessing Islamic finance products. Many Islamic banks focus on Murabahah, which is debt-based financing against equitybased financing of Musharakah and Mudarabah. The reluctance of Islamic banks against equity-based financing is mainly due to the long-term nature of investment usually involved. Islamic banks also face high transaction costs in the form of Shariah verification exercise, which is often passed to entrepreneurs. Similarly, there is inadequate knowledge and awareness of the Islamic finance products and services available to entrepreneurs. Islamic banks do not also collaborate adequately among themselves. Only one Islamic bank, Jaiz Bank Plc., operated in Nigeria until recently when Taj Bank was also licensed. Although there are Islamic windows of some conventional banks, cooperation and collaboration are yet to be noticed among them. There is a need for collaboration in terms of liquidity management, training, and share capital. Such an alliance could attract more stakeholders and investors to provide capital for entrepreneurs.

Another challenge is religious prejudice against Islamic banks. According to Anifowose (2015), Islamic banks raised a lot of fumes in Nigeria and the world over. However, it was only in Nigeria, due to religious intolerance and ignorance, that Islamic banks raised unnecessary smokes. A number of individuals are either not informed or misinformed about the opportunities provided by Islamic banks for entrepreneurs and small business owners. Many non-Muslim countries in Sri Lanka, in recognition of these opportunities, have considerable growth in Islamic banks. Entrepreneurs could also face hurdles in accessing finance from Islamic banks due to improper business planning, deficit cash flow and the small size of the loan being requested. Small entrepreneurs could overcome this challenge if they come together in the form of cooperatives and partnerships to access finance from Islamic banks. If these issues are addressed, the Islamic bank will be able to mitigate existing challenges and support entrepreneurship growth in Nigeria.

\section{Methodology}

The study is based on the conceptual and it has reviewed past studies, both empirical and theoretical, on the concept of Islamic banking and finance such as Musharakah, Mudarabah, 
Murabahah, Ijarah, Salam, Istisna, Tawarruq Financing and Qard Hassan as an option to financing entrepreneurship in the post-covid-19 era. The primary method and approach adopted in this study was a review of the existing relevant literature on the concepts of Islamic banking and finance, aiming at how this can finance and improve entrepreneurship in the post-Covid-19 era through this concept in order to alleviate the issues of unemployment, insecurity, and equality. Therefore, the study reviewed previously published articles relevant to the study, such as articles, journals, conference papers, online publications that were appropriate for the study.

\section{Findings and Discussion}

Based on the past studies reviewed, it can be concluded that Islamic banking and finance are able to respond to financing entrepreneurship in the post-covid-19 era in Nigeria. It is well-known that existing past literature has revealed the positive and favourable association of Islamic banking and finance on financing SMEs in Nigeria. To this effect, these Islamic products can tackle the effects of Covid-19 in society and the community at large. The Covid-19 pandemic has disturbed the entire finance globally as everyone around the world, from policymakers to researchers, is attempting to find a way out and stable sustainable for entrepreneurship. Even though the current crisis is diverse from the 2008 crisis, but the confidence and experience of Islamic banking and finance will play a significant role in re-establishing SMEs after the Covid-19 pandemic as an alternative to traditional financing. On the final note, Islamic banking and finance are rapidly growing in the field of the international finance system. It comprises major philanthropic activities that are targeted to financing SMEs improvement such as Qard Hassan, Zakat and Sadaq are good examples that demonstrated that Islamic banking and finance considers protecting the right of the underprivileged by supporting the distribution of excess income by the wealthy to entrepreneurs who are affected by the effect of Covid019 pandemic (Hassan et al., 2020). In view of this, Islamic banking and financing is a potential instrument to funding many businesses and projects affected through the Covid-19 pandemic, such as Musharakah, Mudarabah, Murabahah, Ijarah, Salam and Istisna. Islamic banking and finance consider wealth distribution and not wealth accumulation among minority people.

Also, the past studies demonstrated that Islamic banking and finance is a significant instrument to enhancing entrepreneurship in the post-covid-19 era in Nigeria. Without a doubt, it is assisting people in various areas positively, which contributes to the country's economic development (AbdulKareem et al., 2021; Raza Rabbani et al., 2021). Besides, Islamic banking and finance have the foundation to build economic development to make life easier for people, protect human nobility and guarantee the wellbeing of life. The important theory behind Islamic banking and finance is the principle of social justice, equality, and fairness. Islamic banking and finance originate from the fundamental values of Islam, which is considered economic justice, equality, fairness, and endless commitment to the wellbeing and securing future generation by protecting the environment. Having stated above, it is vital to add that Islamic banking and finance have a potential role in the country's economic development in the post-Covid-19 era. 


\section{Conclusion and Recommendation}

The above discussion shows the importance of entrepreneurship to the economy. It also presents opportunities available in Islamic finance to provide adequate financing support to entrepreneurs. The discussion highlights the challenges entrepreneurs face in both conventional and Islamic finance options but emphasize that Islamic finance is more aligned and supportive of entrepreneurship, especially through its profit and loss sharing financing. In the light of the above, the study recommends that government should support and encourage entrepreneurs to relate with Islamic banks. There should be adequate education of entrepreneurs on the opportunities and usefulness of Islamic banks. Government should also invest in rural operations of Islamic banks in order to support entrepreneurship. Nigeria is in dear need of investment in rural areas that are largely abandoned. This will reduce the rate of unemployment, insecurity, and restiveness both in rural and urban areas. Government should continue to promote entrepreneurship education in our tertiary institutions. There should be continuous workshops and training on entrepreneurship, especially among youths in order to acquire skills. It is important to strengthen entrepreneurship by providing modern techniques and equipment. The provision of cash does not encourage productivity but rather leads to inflation and laziness. This study only presents the conceptual understanding of entrepreneurship and Islamic finance. Future research is recommended to study practical applications of these concepts to show how Islamic banks actually support entrepreneurship.

\section{References}

AbdulGaniyy, A. K. (2018). Liquidity Risk, Profitability and Cost Efficiency of Islamic banks. Published UUM PhD Thesis . Latvia, European Union.: LAMBERT Academic Publishing.

AbdulGaniyy, A., \& AbdulKareem, I. A. (2020). Islamic Banking and Global Financial Crises: A Review of Liquidity Risk Management. Islam Universalia, 2(1), 153-170.

AbdulKareem, I. A., AbdulGaniyy, A., Mahmud, M. S., \& Yazid, A. S. (2020). Alternative Way to Reducing Poverty and Inequality in Nigeria from Islamic Perspective. Journal of Islamic Banking and Finance, 37(2), 73-83.

AbdulKareem, I. A., Olaide, K. M., \& Isiaka, O. S. (2021). Curbing Unemployment and Brain Drain Among Nigerian Youths Through Islamic Financing Instruments. Journal of Islamic Economic and Business Research, 1(1), 59-71.

Adamu, I. Y., \& Hammawa, Y. M. (2018). Conceptual Analysis of Islamic banking contribution towards Entrepreneuship development in Gombe State Nigeria. IOSR Journal of Business and Management(IOSR-JBM), 20(4), 33-39. Retrieved from http://www.iosrjournals.org

Adedeji, A. S. (2021). Islamic financing effects on small and medium entreprises competitiveness. Journal of Islamic Economic and Business Research, 1(1), 100-113. doi:10.1896/jiebr.vlil.11753

Akinade, E. (2016). Contemporary Entrepreneurship and Career Development. Ibadan, Nigeria: Brightways Publishers.

Alaro, A. A. (2020). CBN Non-Interest Intervention: What is in It for You? Retrieved 2020

Anggadwita, G., Alamanda, D. T., Ramadani, V., \& Ratten, V. (2017). Entrepreneural intentions from an Islamic perspective: a study of Muslim entrepreneurs in 
Financing Enterpreneurship in Post-COVID-19 Era: the Islamic Banking and Finance Option

AbdulFattah AbdulGaniyy, Ibraheem Alani AbdulKareem, Aminu AbdulRaheem

Page: 193-201

Indonesia. International Journal of Entrepreneurship and Small Business. doi:10.1504/IJESB.2017.10064845

Anifowose, L. (2015). The effects of non-interest bankingon entrepreneurship in Nigeria. Journal of Entrepreneurship and Organization Management, 4(4). doi:10.4172/2169-026x.10001`57

Hamzah, A. A., \& Gazali, H. M. (2015). The roles of Islamic financing towards the successful of Islamic MicroEnterprise: A study of Labuan. International Journal of Business Economics and Law.

Hassan, M. K., \& Hippler, W. J. (2014). Entrepreneurship and Islam: an overview. Econ Journal Watch 11(2), 170-178.

Hassan, M. K., Rabbani, M. R., \& Ali, M. A. M. (2020). Challenges for the Islamic Finance and banking in post COVID era and the role of Fintech. Journal of Economic Cooperation \& Development, 41(3), 93-116.

Herianingrun, S., Ratnasari, R. T., Widiastuti, T., Mawardi, I., Amalia, R. C., \& Fadhlillah, H. (2019). The Imact of Islamic bank financing on business. Entrepreneurship and Sustainability Issues, 7(1). doi:http://doi.org/10.0770/jesi.2019.7.1(11)

Islamic Finance Service Board. (2018). Islamic Financial Services Industry Stability Report. IFSB.

Ledhem, M. A., \& Moussaoui, W. (2021). Islamic finance for entrepreneurship activities and economic growth: a parametric and non-parametric analysis from Malaysia. PSU Research Review. Retrieved from http://www.emerald.com/insight/2399.1747.htm

Raza Rabbani, M., Rahiman, H. U., Atif, M., Zulfikar, Z., \& Naseem, Y. (2021). The Response of Islamic Financial Service to the COVID-19 Pandemic: The Open Social Innovation of the Financial System. Journal of Open Innovation: Technology, Market, and Complexity, 7(1), 85.

Riza, H., Ahmed, F. O., \& Ahmed, F. (2017). Islamic banking for small and medium enterorises (SMEs): Aglance at challenges and prospects in Pakistan. International Journal of Development and Sustainability, 6(12), 1998-2008.

Robert, D. H., Michel, P. P., \& Dean, A. S. (2008). Entrepreneurship. New Delhi: Tata-McGrawHill.

Salehi, M., Hematfar, M., \& Khatiri , M. (2011). Entrepreneurship gap in Islamic banking sector: empirical evidence of Iran. African Journal of Business Management, 5(8), 3322-3329. doi:10.5897/AJBM 10.1452

Shehu, F. M., Ahmad, N. H., \& Al-Aidaros, A.-H. (2015, December). Entrepreneurship in the light of Maqasid Al-Shariah: A critical review. Journal of Social and Development Sciences, 6(4), 6-14.

Tawfiqi, D. N., Hamdan, A., Masfaka, M. M., \& Muwafak, B. M. (2018). The role of Islamic banks in the Entrepreneurial Success: Evidence from Bahrain. International Journal of Entrepreneurship, 22(2).

Thaker, M. A., Thaker, H. M., Pitchay, A. B., Amin, M. F., \& Khaliq, A. B. (2020). Leveraging Islamic banking and finance for small business: exploring the conceptual and practical dimension. Asian Development Bank Institute. Retrieved from http://www.adb.org/publication/leveraging-islamic-banking-finance-smallbusiness

Wale-Awe, 0. (2010). Entrepreneurship Development. Lagos: Gilgal Creations and Publication.

Wold Bank. (2016). World Trade Report. 